\title{
"I TEACH CHARACTER IN MY CLASS": INTEGRATING CHARACTER EDUCATION IN EFL READING CLASSROOM AT ISLAMIC HIGHER EDUCATION
}

\section{Siti Nuraeni Muhtar}

Universitas Islam Negeri (UIN) Sunan Gunung Djati Bandung

Jl. A. H. Nasution No. 105, Cibiru, Bandung, Jawa Barat, Indonesia 40614

Email: siti.nuraeni@uinsgd.ac.id

\section{Dahlya Indra Nurwanti}

Universitas Islam Negeri (UIN) Sunan Gunung Djati Bandung

Jl. A. H. Nasution No. 105, Cibiru, Bandung, Jawa Barat, Indonesia 40614

Email: dahlyanurwanti@uinsgd.ac.id

\section{R. Nadia R. P. Dalimunthe}

Universitas Islam Negeri (UIN) Sunan Gunung Djati Bandung

J1. A. H. Nasution No. 105, Cibiru, Bandung, Jawa Barat, Indonesia 40614

Email: rn.dalimunthe@uinsgd.ac.id

Received: 01, 2019. Accepted: 01, 2019. Published: 01, 2019

\begin{abstract}
This article explores teacher's experiences and students' perceptions of character and values education at the university level. This is a case study of how teacher integrates character education in EFL Reading Comprehension subject at Islamic higher education context. The data from ten students and a teacher are collected through an online interview and questionnaires. The result showed the characters implied in EFL Reading Comprehension Subject are eleven characters include learning method, critical thinking, independence, creativity, courage/self-confidence, communicativeness, responsibility, honesty, religiousness, cooperation, tolerance. Those characters are positively responded by the students in their learning process in the classroom. Besides, the teacher also integrated those values in the teaching and learning process to instill students' character education.
\end{abstract}

Keywords: Character Education, Moral Values, English Subject, Islamic Education Department, Islamic University

\begin{abstract}
ABSTRAK
Artikel ini mengeksplorasi pengalaman guru dan persepsi siswa tentang karakter dan nilai-nilai pendidikan di tingkat universitas. Ini adalah studi kasus tentang bagaimana guru mengintegrasikan pendidikan karakter dalam mata pelajaran EFL Reading Comprehension pada konteks pendidikan tinggi Islam. Data dari sepuluh siswa dan seorang guru dikumpulkan melalui wawancara online dan kuesioner. Hasil penelitian menunjukkan karakter yang ditanamkan melalui pembelajaran EFL Reading Comprehension mencakup sebelas karakter yakni metode pembelajaran, berpikir kritis, kemandirian, kreativitas, keberanian / kepercayaan diri, komunikasi, tanggung jawab, kejujuran, agama, kerjasama, toleransi. Karakter-karakter tersebut direspon positif oleh siswa dalam proses belajar mereka di kelas. Selain itu, guru juga mengintegrasikan nilai-nilai tersebut dalam proses belajar mengajar untuk. menanamkan pendidikan karakter siswa
\end{abstract}

Kata Kunci: Pendidikan Karakter, Nilai moral, Pelajaran Bahasa Inggris, Departemen Pendidikan Islam, Universitas Islam 


\section{INTRODUCTION}

Character education becomes an integral part of the education field. Since there are so many criminal cases happened especially related to the young generation, character education seems to be an important factor to improve. Character education is the acquisition and strengthening of virtues, values, and the capacity to make wise choices for a well-rounded life and a thriving society (Berkowi, 2014). Character education related to the social, emotional and ethical development of learners by instilling in them important core, ethical and performance values such as caring, honesty, diligence, fairness, fortitude, responsibility, and respect for self and others. It also provides long-term solutions to moral, ethical, and academic issues of concern in society and schools and teaches learners how to be their best selves and how to do their best work (Character Education Partnership). Every education level should implement those values of character education because students experience longer time at school more than at their house. However, it is the different case regarding the higher education level. The implementation seems to be more challenging related to the dynamic condition and environment especially in Islamic higher education environment where moral values become a strong core of education. Therefore, this study is trying to investigate the character education implementation performed by the lecturers in the way they deliver the materials in Islamic Education Major in Islamic higher education level taking the case in English as Foreign Language (EFL) Reading Comprehension subject as one of the general subjects taught.

It is interesting to note that in Indonesia, reading comprehension in Islamic higher education is one of compulsory material for every major. It becomes a big question related to how the teacher implements the character education. The relation between the materials and the implementation in teaching and learning activities are even more challenging. Moreover, the study of this topic is found to be really rare to investigate. Thus, this study is carrying out to describe the phenomena happened on the field.

Character education refers to moral education, values education, values in education, values education, character development or developmental education. Character education is aligned with more conservative, traditional, and behavioral approaches while moral education is aligned with more liberal, constructivist, and cognitive approaches (Berkowi, 2014). On the other hand, values education is aligned with theoretical, attitudinal, empirical approaches. Given the conflicts between the different approaches, Berkowitz suggests a dialectical approach to character education, noting that the approach could enhance collaboration and networking to establish the character qualities relevant in today's dynamic world. Nurturing learners with relevant character qualities is crucial because it empowers with skills that enable them to cope with the complex societal challenges of the 21 st-century world and to also compete for jobs at international level. Character education is an integral component of the 21 st century skills and also notes that the 21 st century skills such as critical thinking, problem solving, communication and collaboration are founded on UNESCO's four pillars of learning (Learning to know, Learning to do, Learning to be and Learning to live together) which represent a holistic view of an education that addresses the whole person-the mind, the body and soul/character (Chowdhury, 2018).

\section{METHOD}

This research is a case study conducted in an EFL reading comprehension class of Islamic Education Department, in an Indonesian state university. This study aims to explore students' perceptions and teacher's experiences of character education in the classroom. Data was collected through an online questionnaire, which was distributed to 10 students. The questionnaire includes 10 open-ended questions derived from the 10 characters, targeted by the department, namely critical thinking, independence, creativity, courage/self-confidence, 
communicativeness, responsibility, honesty, religiousness, cooperation, tolerance. The questionnaire responses are analyzed to find out what they think of the character education in the learning process of the subject. In the interview, the teacher got 60 questions, related to the teacher's understanding of character education, how she manifests them in the teaching, and obstacles, challenges, and successes she gets during the process.

\section{RESULTS AND DISCUSSIONS}

1) Students' Perceptions

a. Learning methods

From the questionnaire, it is shown that all the respondents agree that the lecturer applies inquiry-based learning method. Its evidence are the implementation of brainstorming, question-and-answer, class and group discussions, and presentation. According to Ismail and Elias (2006), the principle of inquiry-based learning is the learners' "personal discovery". Here, the learners are guided to make questions and find the answers through the critical thinking process.

However, the inquiry-based learning implemented here - according to the students' answers - focuses mainly on active learning in which all learning activities are guided by the lecturers. In brief, the lecturer starts the lesson by explaining the material (lecturing) and followed by brainstorming in which she asks questions related to the material and encourages the students to answer them individually. Afterward, the students are put into groups and have a discussion to understand the text given and answer the questions about the text. At last, the students are instructed to have a group presentation to share the result of their discussion with the class.

From the above explanation of the teaching method applied by the lecturer of Reading Comprehension subject, at least three attributes of meaningful learning (Jonassen \& Jonassen, 2003) are featured in the learning process; they are active learning, constructive learning, and cooperative learning. The evidence of active learning is the students' collaboration (Achmad, 2013) in answering the questions of the text. Meanwhile, the question-and-answer session which enables the students to respond to the lecturer becomes the evidence of constructive learning. Those two attributes are also shown in the discussion and the presentation which become the core of a cooperative learning attribute.

The next part of the discussion of the research result would examine how the learning methods help to internalize the character education.

b. Critical Thinking

Based on the questionnaire, all the respondents agree that the learning process helps them train their critical thinking skill. The brainstorming, the question and answer session, the exercises and the assignments given by the lecturer require the students to think critically. Many times, the lecturer asks them to make arguments over a topic in the text being discussed. It is especially when they are asked to make a prediction about the text, finding the main ideas, and making inferences. In addition, critical thinking is also required when the students are given writing assignments.

It is in line with Lai (Cheung \& Jhaveri, 2016; Olson \& Valeri-Gold, 1991) who argues that critical thinking involves "analyzing arguments, making inferences using inductive or deductive reasoning, judging or evaluating, and making decisions or solving problems." Students need to be exposed with questions, problems, and projects to encourage their critical thinking, and the lecturer has provided them with those inquiries. For English Reading Comprehension subject, the questions and problems are well in the forms of making arguments or opinion regarding the texts, while the projects are in the form of writing critical 
responses on the content of the texts; both of which are already implemented by the lecturer. In other words, students believe that they learn well to think critically in this subject.

c. Independence

The results of the questionnaire show that the students think their independence of learning is also trained in the learning process. No respondents state the opposite. It is specifically in the assignments given by the lecturer. While the classroom activities require the students to work together and collaborate with their peers, most of the assignments are individual works. In completing the individual works, the students are encouraged to be independent in a way that they should manage themselves and their own ideas to get things done. Even though many experts believe that group work is more effective than individual work (Sanderse, 2013), there are times when individual work is preferred considering students' individual learning style and the character education being internalized. Individual works are still necessary whatsoever since there are some elements of learning evaluation that cannot be examined through group work. Eventually, students are expected to have good individual skill even when the tasks are group works.

d. Creativity

On creativity, most respondents agree that the learning process designed by the lecturer require them to be creative, specifically in the use of English for communication. They argue that they need to be creative to be able to produce English sentences either orally or in writing. In this sense, the respondents connect the creativity of using a language with critical thinking. Meanwhile, a respondent states that the learning process does not involve creativity from the students' side since the activities and assignments only require them to use good English. Here, the problem lies in how students' define creativity, and not on whether or not the lecturer design activities and assignments that encourage the students to be creative. Creativity is a broad concept, meaning that there is a wide variety of words that can be associated with it (Lee, 2013). At last, it can be assumed that the lesson designed by the lecturer indeed involves students' creativity, specifically for communicating using English.

e. Courage/self-confidence

Examining the internalization the characters of courage/self-confidence in the Reading Comprehension class, the respondents agree that this character is strongly encouraged by the lecturer. Especially in the question-and-answer sessions and the presentations, students are required to speak up, thus training their courage/self-confidence. According to the respondents, the lecturer always motivates them to speak their minds. It is essential in English language learning since for the learners to be able to use the language, they need more practices. In the theory of meaningful learning, it is in line with the principle of authentic learning (Jonassen \& Jonassen, 2003) in which the new knowledge, in this case, is English vocabulary, is applied into real-life situations. Therefore, it can be said that the lecturer is successful in internalizing the character of courage/self-confidence into the lesson.

f. Communicativeness

According to the respondents, when the lecturer asks questions regarding the material and in the group presentation, they are encouraged to speak up, resulting in their ability to be communicative. As the lecturer keeps providing problems to be solved by the students, they continue to communicate with each other (both the lecturer and peer students). As it is previously mentioned, for the success of learning, students need to be exposed to the real use of the knowledge. In other words, for the students to be able to communicate in English, they need to be exposed to contexts and situations in which they are forced to use English.

g. Responsibility

As it is previously mentioned, the lecturer gives the students individual assignments in addition to the in-group classroom activities. Based on the questionnaire results, the 
respondents agree that, besides training their independence in learning, the assignments also require them to be responsible. Since scores are taken also from the assignments, it is an obligation that the students complete and submits them. The respondents also argue that to be able to succeed in completing the group works, each individual member needs to show their responsibility. Some of them also highlight that when they share their opinions and make arguments about a topic, they need to provide logical reasons, which means showing their responsibility for what they are saying. That evidence proves that the character of responsibility is included in the lesson.

h. Honesty

All respondents agree that the English lesson designed by the lecturer also trains their honesty. They specifically point out the assignments and evaluation process. Originality is a very important value in learning a language. Therefore, this principle becomes an important point of evaluation.

i. Religious-ness

As an Islamic education institution, religiousness is important to be internalized in the students. According to their responses to the questionnaire, most respondents stated that religious value is also internalized in the lesson. They explain that the lecturer often connects the materials from the book with Islamic value. There are also some materials about Islamic culture and the holy Quran. In addition, two respondents also point out that the Islamic values they learn in the Reading Comprehension lessons are also in the forms of attitude such as trustworthiness and politeness which they need to show while interacting with their lecturer and their friends.

However, two of the respondents say that the lesson does not involve religious value because it only focuses on language learning. The opposite opinions might reflect how the internalization of this value is not optimally conducted. While there is indeed religious value reflected in the lesson, it is not explicit enough that some students do not realize it.

j. Cooperation

As it is pointed out before, the lecturer applies group discussions in the lessons. The respondents agree that this activity optimally trains their ability to be cooperative with each other. In addition, they also point out how the cooperation can take place when they ask their friends, instead of the lecturer, questions about English that they do not know.

k. Tolerance

All the respondents once again agree with a point of how character education is involved in the English lesson. Based on the responses, the value of tolerance is present in the learning process. However, the tolerance being discussed here is not about race, ethnicity or culture. Instead, it is about how students in a class might have different levels of English proficiency and how they might have a different opinion about a topic. The former means that nobody is supposed to feel superior or inferior to the others in terms of English ability because they are all still in the process of learning. Meanwhile, the latter means that when the students have different opinions with each other, they are supposed to respect each other. To conclude, the lessons designed by the lecturer enable the students to learn the value of tolerance.

2) Teacher's Experiences

a) Teachers' Understanding of Character Education

From the teacher's perspective, character education is essential to equip students not only with cognitive abilities but also with emotional intelligence and noble behaviors. This is relevant with Presidential Decree No. 87 of 2017, concerning Strengthening Character Education (PPK), which implements character education as a national education platform to equip students as the golden generation of 2045 with the spirit of Pancasila and good character to deal with the dynamics of change in the future. She added that the overall 
characters, set by the Islamic Education Department, are attached to society, spirituality, and culture (Chowdhury, 2018). She perceives her role in the classroom as a role model. Sanderse (2013) argued that teachers need to understand why modeled traits are morally noteworthy and how students can get these qualities. Moreover, regarding the character-education practice, the teacher understands that the ten characters cannot be internalized separately in a single activity. They are mutually included in the class activities and materials. She argued that it is impossible to teach the ten characters separately because they are reciprocally connected. For example, group work requires students to work in teams. In this teamwork, students also learn to accomplish their jobs genuinely.

b) Manifesting Characters in Classroom Activities

Of the ten characters, critical thinking is the most challenging character to be involved in her practice. Critical thinking has been immersed in all aspects of reading activities through inquiries-based method. She argued her inquiries encouraged her students' argument skills. It is a good help for students to be a critical thinker (Kuhn, Hemberger, Khait, Hemberger, \& Khait, 2017). Her practice rooted in peer or classroom dialogue. For example, in the prereading activity, students' critical thinking was triggered by inquiring a debatable still picture. It was to build her students' critical thinking through visual literacy - critical viewing skills (Cheung \& Jhaveri, 2016). Additionally, in the while reading activity, the teacher elaborated some questions of the textbook to insist her students to read a text closely, eventually to extract meanings manifested in a text (Sno \& O'connor, 2013).

Cooperation, in her practice, is established with group work. Group work is realized in almost the entire series of reading stages. For example, the teacher forms student discussion groups in pre-reading, which then continue to be collaborative reading and structured group assignments. From her perspective, group work is thriving to accelerate student discussion spaces and motivate low students to involve in the discussion. This practice fits the two sides of collaborative learning, namely collaborating to learn (collaborative learning environments to stimulate productive learning) and learning to collaborate (Häkkinen et al., 2017).

Independence, self-confidence, and communication are closely internalized in her teaching. She said that her students, who showed their independence, looked more confident and communicative. The interrelation among the characters has been proven by previous scholars (Gürler, 2015; Phillips, Smith, \& Modaff, n.d.; Tagay \& Karakelle, 2014; Vatankhah, Daryabari, Ghadami, \& Naderifar, 2013; Yahaya \& Ramli, 2009). The three characters usually appeared in class discussions. For example, when the teacher posed a challenging question, students independently competed to the answer. Those who answered confidently were able to convey their message well. To stimulate the characters, the teacher gave praise to those who have ventured to answer her questions and motivated her silent students. These efforts are regarded as the teacher's emotional support which is important to high-quality instruction and has been proven to support students' motivation and engagement (Ruzek et al., 2016). She also provided her student's sufficient spaces for independent work, such as students' individual presentations or written assignment. Even though, a lot of previous research results show that completing the tasks collaboratively lead to a greater success of task completion than completing them individually (Alfares, 2017; Burdett, 2003; Dobao, 2014), group work does not lead to significantly greater gains of knowledge than individual tasks (Nassaji \& Jun Tian, 2010).

Honesty and responsibility are the other mutual characters. Many tasks require the two reciprocally. Honesty is transmitted in the form of student-work originality, which then also becomes part of their responsibilities. Responsibility is embodied in students' ability to fulfill their obligations in the class honestly and nobly. In teacher experience, these two characters cannot be encouraged by oral motivation. The teachers need to apply a strict classroom 
setting, regular feedback to students' assignments and a transparent assessment. For example, the teacher always checks students' plagiarism opportunity and provides feedback on their assignments as an assessment of their work quality and the source of learning. Teacher's constructive feedback effectively reduces and avoids students' plagiarism (Anyanwu, 2003; Badge, Cann, \& Scott, 2007; Hyland, 2001)

Religiousness and tolerance are most likely embodied in class routines. For example, students are accustomed to praying and greeting before starting learning and keeping the classroom silent and conducive when the teacher or one friend speaks. To instill a broader concept of religion and tolerance, the teacher presents debatable trending topics in class or group discussions. The discussion builds students' stronger understanding of religion and religiosity, which is further expected to be penetrated in students' lives. Moreover, dissents train students to respect others' opposite opinions. The teacher believes that students have acquired cultural values, religious diversity, and tolerance from family and society. Therefore, she has a role in creating a deliberate culture of tolerance and religion in the class. Raihani (2014) argued teachers play an essential role in motivating students' understanding of religious diversity and tolerance through deliberate teaching about religiousness and tolerance.

Creativity is required by the teacher in each task. However, the teacher argued that her students cannot bring their creative ideas out optimally. Students tend to follow the existing examples. From the teacher's perspective, in this regard, their "too-obedient" attitude is not beneficial. The teacher added that students fulfill their obligations well but do not provide any innovation. In fact, they are able to express extraordinary ideas in class discussions but tend to be on the safe side while doing assignments. Students' anxiety has been proven to create a difficult environment in the creative classroom (Ahadnejad Tabrizi, Mansor Abu Talib, \& Nor Yaacob, 2011; Jafarigohar \& Behrooznia, 2012; Shehayeb \& Anouti, 2018).

c) The Most Successful Classroom Activities

The class activity that most attracts students; participation is a discussion of controversial trending topics. From the teacher's point of view, students are very active and critical in assessing current social events. Topics that are familiar with students increase students' participation in discussion and class assignments (Weaver \& Qi, 2015). Moreover, the question and answer session that ended the class discussion was always in profusion. The teacher added that students were happy if they were chosen to answer the question and express their opinions. They enjoyed being recognized and appreciated. In education, positive recognition can improve students' extraordinary performance. Students perceive work as a source of pleasure and can even be a flowing experience. Recognition between teachers and students builds a strong sense of solidarity, which makes them important and respected members of the community (Huttunen \& Heikkinen, 2006).

d) Barriers and Challenges

Three barriers have been identified during the teacher's teaching. Firstly, she has not found a suitable formula to incorporate critical thinking and her teaching materials, and also her practice. She said that the existing textbooks could not really engage her students' critical thinking. Martins (2013) noted that teachers and students depend on the textbook material. Hence, the textbook provides a solid basis for beginner teachers who have weak confidence in developing their lessons by using the communicative approach (Badea \& Iridon, 2015). Miguel (2015) added that the relationship between teacher, textbooks, and learner establishes how teaching-learning develops within a classroom. Secondly, group work does not benefit all students. Barriers to group work actually come from students' psychological aspects. Students who are overly individual-egocentric would probably dominate the group and unintentionally intimidate more introvert students. Alfarez (2017) reasoned that some learners identified difficulties in group work, mostly associated with learners' behaviors, which result in 
uncooperative interaction in groups. This may prevent them from obtaining the benefits of group work. Thirdly, students' anxiety for acting creatively causes the teacher's low satisfaction. The student questionnaire results show that creativity is perceived in terms of cognitive ability, while the teacher expects students developing their creativity more than it. The teacher needs to explain her tacit expectations of student work clearly. Unclear expected outcomes will lead students to confusion and an assessment gap (König et al., 2016; Mulliner \& Tucker, 2017).

\section{CONCLUSION}

Islamic higher education initiatives discussed above all have an implicit character education development dimension that is defined by a particular core of moral values. These moral values have implemented in teaching and learning activities specifically in EFL Reading Comprehension subject as a general subject at university level. The university might view these contents as a common core content of character education. However, these values can define the character education that builds the students' awareness to improve their quality of life and avoid moral degradation. Emphasis varies by institutional type, but there is widespread agreement on the core of values that define moral conduct, and these values constitute a de facto understanding of characters that is widely accepted and promoted by Islamic University today, especially in Indonesia. This common conception of good character emphasizes ten characters, targeted by the department, namely critical thinking, independence, creativity, courage/self-confidence, communicativeness, responsibility, honesty, religiousness, cooperation, tolerance. Besides, the teacher also integrated those values in the teaching and learning process to instil students' character education.

\section{BIBLIOGRAPHY}

Tabrizi, E. A, Talib, A. M. A., \& Yaacob, N. S. (2011). Relationship between creative thinking and anxiety among adolescent boys and girls in Tehran, Iran. International Journal of Humanities and Social Science (Vol. 1).

Alfares, N. (2017). Benefits and difficulties of learning in group work in EFL classes in Saudi Arabia. English Language Teaching, 10(7), 247. https://doi.org/10.5539/elt.v10n7p247

Anyanwu, R. (2003). Lessons on plagiarism: Issues for teachers and learners. International Education Journal (Vol. 4).

Apedoe, X. S., \& Reeves, T. C. (2006). Inquiry-based learning and digital libraries in undergraduate science education. Journal of Science Education and Technology, 15(5-6), 321-330. https://doi.org/10.1007/s10956-006-9020-8

Badge, J. L., Cann, A. J., \& Scott, J. (2007). To cheat or not to cheat? A trial of the JISC plagiarism detection service with biological sciences students. Assessment \& Evaluation in Higher Education, 32(4), 433-439. https://doi.org/10.1080/02602930600898569

Berkowi, M. (2014). Character and citizenship. Retrieved January 22, 2019, from https:// characterandcitizenship.org/about-us/key-players?id $=8$.

Burdett, J. (2003). Making groups work: University students' perceptions. International Education Journal, 4.

Lee, B. (2013). The concept of creativity and linguistic creativity and its pedagogical implications in foreign language education. Journal of Korean Language Education, null (31), 141-168. https://doi.org/10.17313/jkorle.2013..31.141

Cheung, C. K., \& Jhaveri, A. D. (2016). Developing students' critical thinking skills through visual literacy in the new secondary school curriculum in Hong Kong. Asia Pacific Journal of Education. https://doi.org/10.1080/02188791.2014.959470

Chowdhury, M. (2018). Emphasizing morals, values, ethics, and character education in science education and science teaching. Adum.Um.Edu.My. 
Dobao, A. F. (2014). Attention to form in collaborative writing tasks: Comparing Pair and small group interaction. Canadian Modern Language Review, 70(2), 158-187. https://doi.org/10.3138/cmlr.1768

Gürler, İ. (2015). Correlation between self-confidence and speaking skill of English language teaching and English language and literature preparatory students. Curr Res Soc Sci (Vol. 1).

Häkkinen, P., Järvelä, S., Mäkitalo-Siegl, K., Ahonen, A., Näykki, P., \& Valtonen, T. (2017). Preparing teacher-students for twenty-first-century learning practices (PREP 21): A framework for enhancing collaborative problem-solving and strategic learning skills. Teachers and Teaching: Theory and Practice, 23(1), 25-41. https://doi.org/10.1080/13540602.2016.1203772

Huttunen, R., \& Heikkinen, H. L. T. (2006). Pedagogy, culture and society teaching and the dialectic of recognition. https://doi.org/10.1080/14681360400200194

Hyland, F. (2001). Dealing with plagiarism when giving feedback. ELT Journal, 55(4), 375-381. https://doi.org/10.1093/elt/55.4.375

Jafarigohar, M., \& Behrooznia, S. (2012). The effect of anxiety on reading comprehension among distance EFL learners. International Education Studies, 5(2). https://doi.org/10.5539/ies.v5n2p159

Jonassen, D. H., \& Jonassen, D. H. (Eds.). (2003). Learning to solve problems with technology: A constructivist perspective (2nd ed). Upper Saddle River, N.J: Merrill.

König, J., Lammerding, S., Nold, G., Rohde, A., Strauß, S., \& Tachtsoglou, S. (2016). Teachers' professional knowledge for teaching English as a foreign language. Journal of Teacher Education, 67(4), 320-337. https://doi.org/10.1177/0022487116644956

Kuhn, D., Hemberger, L., Khait, V., Hemberger, L., \& Khait, V. (2017). Argue with me. Routledge. https://doi.org/10.4324/9781315692722

Mulliner, E., \& Tucker, M. (2017). Feedback on feedback practice: perceptions of students and academics. Assessment \& Evaluation in Higher Education, 42(2), 266-288. https://doi.org/10.1080/02602938.2015.1103365

Nassaji, H., \& Jun Tian. (2010). Collaborative and individual output tasks and their effects on learning English phrasal verbs. Language Teaching Research, 14(4), 397-419. https://doi.org/10.1177/1362168810375364

Olson, J. R., \& Valeri-Gold, M. (1991). Cooperative learning and college developmental readers: An action research project to improve summary writing. Journal of College Reading and Learning, 24(1), 40-45. https://doi.org/10.1080/10790195.1991.10849979

Phillips, J., Smith, B., \& Modaff, L. (n.d.). EQuot; Please don't call on me: EQ Quot; Self-esteem, communication apprehension, and classroom participation.

Raihani. (2014). Creating a culture of religious tolerance in an Indonesian school. South East Asia Research, 22(4), 541-560. https://doi.org/10.5367/sear.2014.0234

Ruzek, E. A., Hafen, C. A., Allen, J. P., Gregory, A., Mikami, A. Y., \& Pianta, R. C. (2016). How teacher emotional support motivates students: The mediating roles of perceived peer relatedness, autonomy support, and competence. Learning and Instruction, 42, 95-103. https://doi.org/10.1016/j.learninstruc.2016.01.004

Sanderse, W. (2013). The meaning of role modelling in moral and character education. Journal of Moral Education, 42(1), 28-42. https://doi.org/10.1080/03057240.2012.690727

Shehayeb, S., \& Anouti, M. (2018). The impact of teacher' practices and content of mathematics on Student' anxiety in secondary and intermediate classes, 29. https://doi.org/10.4172/21671044.1000320

Sno , C., \& O'connor, C. (2013). Close reading and far-reaching classroom discussion: Fostering a vital connection.

Tagay, Ö., \& Karakelle, S. (2014). Self-esteem and communication skills as predictors of psychological resilience for Turkish vocational school students.

Vatankhah, H., Daryabari, D., Ghadami, V., \& Naderifar, N. (2013). The effectiveness of communication skills training on self-concept, self-esteem and assertiveness of female students in guidance school in Rasht. Procedia-Social and Behavioral Sciences, 84, 885-889. https://doi.org/10.1016/j.sbspro.2013.06.667 
Weaver, R. R., \& Qi, J. (2015). Classroom organization and participation: College students' perceptions. Journal of Higher Education, 76(5), 570--601.

Yahaya, A., \& Ramli, J. (2009). The relationship between self-concept and communication skills towards academic achievement among secondary school students in Johor Bahru. 